\title{
POPULASI DAN PERILAKU KERA EKOR PANJANG (Macaca fascicularis) DI DESA PANCASARI SUKASADA BULELENG BALI
}

\section{THE POPULATION AND THE BEHAVIOR OF LONG TAILED MACAQUES (Macaca fascicularis) IN THE VILLAGE PANCASARI SUKASADA BULELENG BALI}

\author{
Ni Putu Kiki Mahayuni, Ni Luh Watiniasih, Deny Suhernawan Yusup \\ *Prodi Biologi FMIPA Universitas Udayana \\ *Email : kikimahayuni@gmail.com
}

\section{INTISARI}

Kera ekor panjang (Macaca fascicularis) adalah jenis kera yang memiliki panjang ekor kurang lebih sama dengan tubuh. Habitat kerasalah satunya berada di Desa Pancasari, Sukasada, Buleleng, Bali.Populasi kera di daerah ini belum diketahui, begitu juga perilakunya belum pernah diteliti. Penelitian ini untuk mengetahui jumlah populasi dan perilakunya. Perhitungan populasi dilakukan dengan metode sensusyang dibedakan berdasarkan umur (a) dewasa, (b) anakan dan (c) infant, sensus dilakukan tiga kali,di pagi hari pada pukul 09.00-10.00 di siang hari pukul 11.00-12.00 dan di sore hari 13.00-14.00. Perilaku dicatat dengan metode fokal animal scan sampling,yang dilakukan padapagi haripukul 09.0011.00dan di sore hari pada pukul 14.00-16.00.Jumlah populasi kera di lokasipenelitian ditemukan sebanyak 252,terdiri dari 96 ekor kera jantan dewasa, 85 ekor betina dewasa, 44 ekor anakan dan 27 ekor infant. Perilakuyang paling banyak dilakukan oleh kera ekor panjang di Desa Pancasari adalah bergerak (30\%),diikuti oleh perilaku makan (27\%) dan istirahat(22\%),perilaku yang paling sedikit adalah agresif dan kawin yaitu masing-masing (2\%).

Katakunci : Macaca fascicularis, populasi, perilaku harian,

\section{ABSTRACT}

Long-tailed macaque (Macacafascicularis) has its name as the length of its tail as long as its body. One of their habitats is located in Pancasari Village, Sukasada, Buleleng, Bali. Its current number and their daily activity has not been scientifically studied. This research, aimed to determine the number of individuals in its age groups, and the in daily activity as. The population was calculateemploying census methodand was distinguish accordingly to different age group (a) adult, (b) juveniles and (d) infant, ceusused three times that inthe morning at 09.00-10.00, during the day at 11.0012.00and in the afternoon at 13.00-14.00. Daily activities of this macaque were recorded withanimal focal scan sampling method, twice in a day, in the morning at 09.00-11.00 and in the afternoon at 14.00-16.00 for 7 days. The population of long-tailed macaques in this are is 252, consisting of 96 adult male, 85 adult females, 44 juveniles and 27 infants. The long tail macaques at Pancasariuse most of their time for moving (30\%), followed by eating (27\%)and resting (22\%). Only $2 \%$ of their daily time was used for aggressive and mating.

Keywords: Macaca fascicularis, population, daily activities

\section{PENDAHULUAN}

Indonesia merupakan suatu negara dengan beragam spesies primata dan sebanyak $20 \%$ primata ditemukan di wilayah Indonesia (Supriatna dan Wahyono, 2000). Keraekor panjang banyak ditemukan di Indonesia,seperti di Pulau Sumatera, Jawa, Bali dan Kalimantan.Keraekor panjangyang ada di Bali jugaditemukandiDesa Pancasari Kecamatan Sukasada Kabupaten Buleleng, Monkey Forest Ubud Kabupaten Gianyar, Alas Kedaton di Kabupaten Tabanan, serta di Pura Uluwatu dan Sangeh di Kabupaten Badung.

Menurut Fooden (2006) populasi kera ekor panjang kurang lebih sebanyak 3 juta individu di seluruh Asia tenggara dari jumlah awalnya sekitar 5 juta individu. Penurunan jumlah kera disebabkan karena kera ekor panjang banyak diperdagangkan dan banyak diambil dari habitat alaminya (Gumert dkk., 2011). Kera ekor panjang termasuk spesies terlindungi karena sering juga digunakan sebagai hewan percobaan dalam penelitian ilmiah (Sajuthi, 1984).

Habitat kera ekor panjang yang ada di Bali umumnya berada di kawasan suci pura dan difungsikan sebagai kawasan objek wisata. Menurut Budayasih (1993), kera ekor panjang berinteraksi dengan masyarakat. Populasi kera ekor panjang yang ada di Desa Sukasada belum pernah diteliti begitu juga perilakunya sehingga, perlu dilakukan penelitianuntuk mengetahui jumlah populasi danperilaku kera ekor panjang di Desa Pancasari, Kecamatan Sukasada, Kabupaten Buleleng,sebagai salah satu habitat kera yang menjadi objek wisata di Bali.

\section{MATERI DANMETODE}

Penelitian dilaksanakan di daerah Desa Pancasari,Sukasada, Buleleng, Bali, dari bulan Januari sampai dengan bulan Februari 2017. Perhitungan jumlah populasi diulang 3 kali pada hari yang sama, yaitu pada pagi hari pada pukul09.00-10.00 di siang hari pukul 11.00-12.00 dan di sore hari 13.00-14.00.

Populasikera dihitung dengan metode sensus. Perhitungan dilakukan dengan cara menghitung langsung setiap individu dan dibedakan berdasarkan umur kera yaitu jantan dewasa, betina dewasa, anakan dan infan. Perilaku kera diamati dengan metode focal animal scan sampling yaitu dengan cara mengamati satu individu hewan fokal secara kontinyu selama 15 menit. Sebelum pengamatan perilaku hewan fokal ditentukan dengan cara mengamati ciri-ciri khusus yang terdapat pada hewan tersebut seperti adanya bekas luka, warna puting susu atau ciri khas lainnya. Perilaku diamati 2 kali sehari, masing-masing pada periode waktu 09.00-11.00 di pagi hari, dan pukul 14.00-16.00 di sore hari selama 7 hari. 


\section{HASIL}

Penelitian di Desa Pancasari,dapat diketahui bahwa jumlah populasi kera ekor panjang (Macaca fascicularis) yaitu sebanyak 252 ekor, dengan jumlah masing-masing usia yaitu 96 ekor jantan desawa, 85 ekor betina dewasa, 44 ekor anakan dan 27 ekor infant.
Jenis makanan yang dimakan oleh kera ekor panjang di daerah Desa Pancasari berasal dari pengelola ataupun pengunjung dan dari alam. Jenis - jenis makanan yang ditemukan dan dimakan, dipresentasikan pada Tabel 1.

Tabel 1. Jenis-jenis makanan kera ekor panjang (Macaca fascicularis)

\begin{tabular}{ccccc}
\hline Waktu & Pisang & Jeruk & Kacang & Daun \\
\hline Pagi & 103 & 57 & 26 & 13 \\
Siang & 84 & 81 & 48 & 15 \\
Sore & 47 & 42 & 28 & 43 \\
\hline Total & 234 & 180 & 102 & 71 \\
\hline
\end{tabular}

Makanan yang dimakan oleh kera adalah pisang, yang paling banyak dikonsumsi di pagi hari, sedangkan jeruk dan kacang banyak dikonsumsi di siang hari. Banyaknya pisang yang dikonsumsi oleh kera di pagi hari karena pisang disediakan oleh pengelola wisata dan pemberian pakan oleh pengelola wisata dilakukan di pagi hari Banyaknya jeruk dan kacang yang dimakan oleh kera di siang hari dengan banyaknya wisatawan yang berkunjung dan memberi jeruk atau kacang kepada kera. Dedaunanyang di dapat dari hutan terlihat banyak dikonsumsi di sore hari. Jenis dedaunan yang dimakan tidak dapat diketahui karena kera berada dikejauhan saat makan dedaunan.

Tipe perilaku yang diamati pada kera ekor panjang dapat di lihat pada (Gambar 2). Persentase perilaku yang paling tinggi dilakukan adalah bergerak, diikuti dengan makan dan istirahat. Perilaku yang sedikit dilakukan adalahperilaku grooming,bermain, kawin dan agresif (Gambar 2).

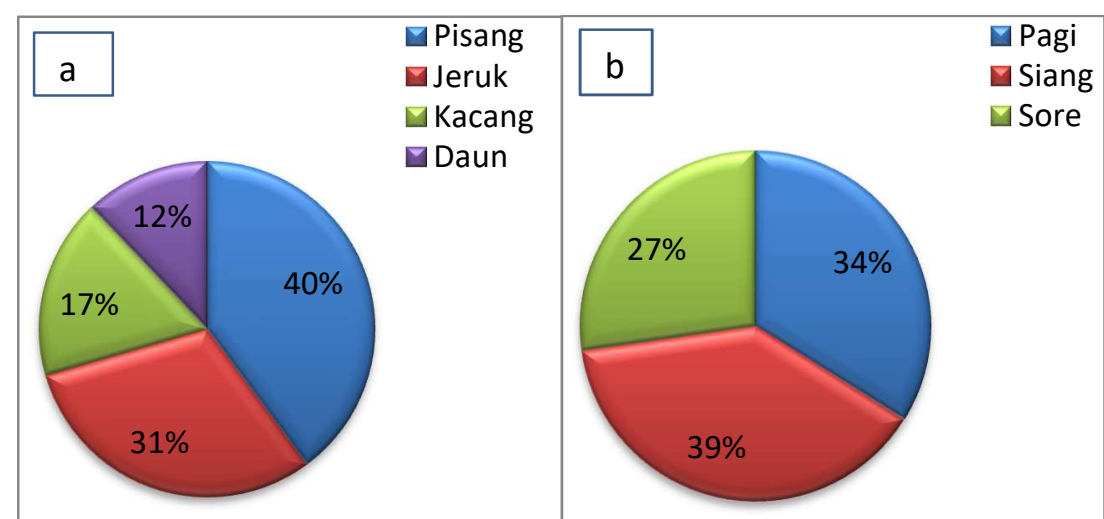

Gambar 1. Jenis-jenis makanan (a) dan waktu makan (b) kera ekor panjang (Macaca fascicularis) di Desa Pancasari

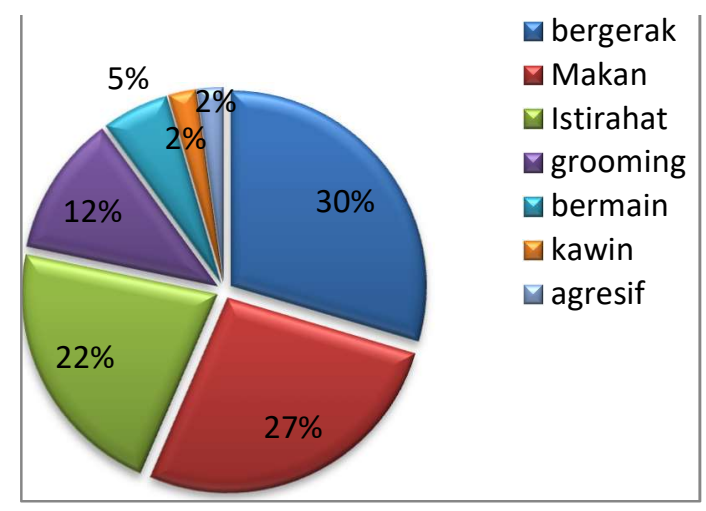

Gambar 2.Perilaku kera ekor panjang (Macaca fascicularis) di Desa Pancasari.

Perilaku yang dılakukan oleh kera ekor panjang, jika dilihat dari waktu berperilakunya sedikit bervariasi dari waktu ke waktu (pagi dan sore). Pada pagi hari, sebagian besar waktunya digunakan untuk bergerak, makan dan 1stırahat, dan hanya sebagian kecil waktunya digunakan untuk bermain, kawin dan berperilaku agresif (Gambar 3). 


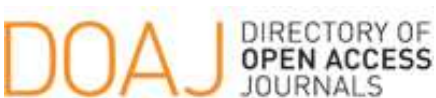

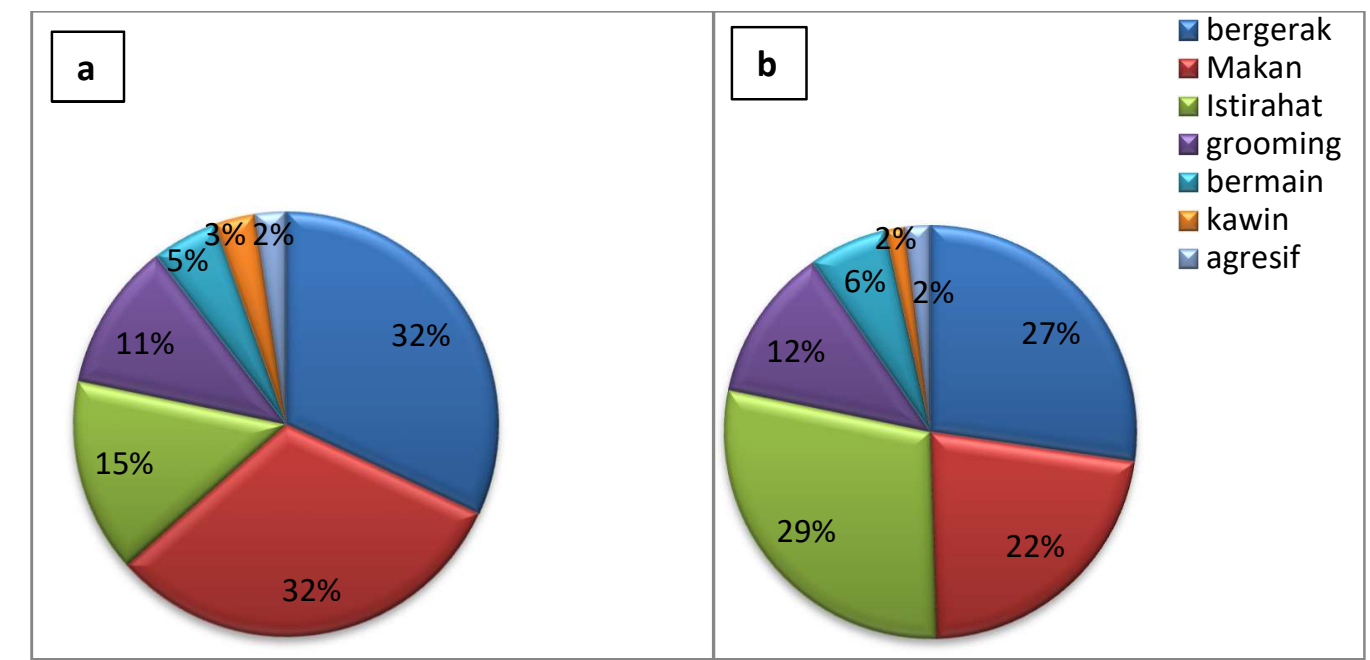

Gambar 3. Perilaku kera di pagi hari (a)dan di sore hari (b) di Desa Pancasari.

Pada sore hari, pola perilakunya tidak banyak berubah, yaitu sebagian besar waktunya juga digunakan untuk bergerak, makan dan beristirahat. Sisa waktu aktifnya digunakan untuk grooming, bermain, kawin dan berperilaku agresif. Berdasarkan jenis kelamin, perilaku kera ekor panjang dewasa tidak banyak berbeda antara betina dan jantan (Gambar 4). Kera betina maupun kera jantan, keduanya menggunakan proporsi waktu yang samauntuk makan (27\%), kera jantan lebih banyak melakukan aktifitas bergerak (31\%) dibandingkan dengan betina (29\%). Sebaliknya, kera jantan lebih sedikit menghabiskan waktu aktifnya untuk beristirahat $(21 \%)$ dibandingkan dengan kera betina (23\%). Waktu aktif kera ekor panjang ini paling sedikit digunakan untuk kawin dan agresif yaitu hanya $5-6 \%$ baik oleh kera betina maupun jantan, dan hanya (12\%) waktunya digunakan untuk grooming (Gambar 4).

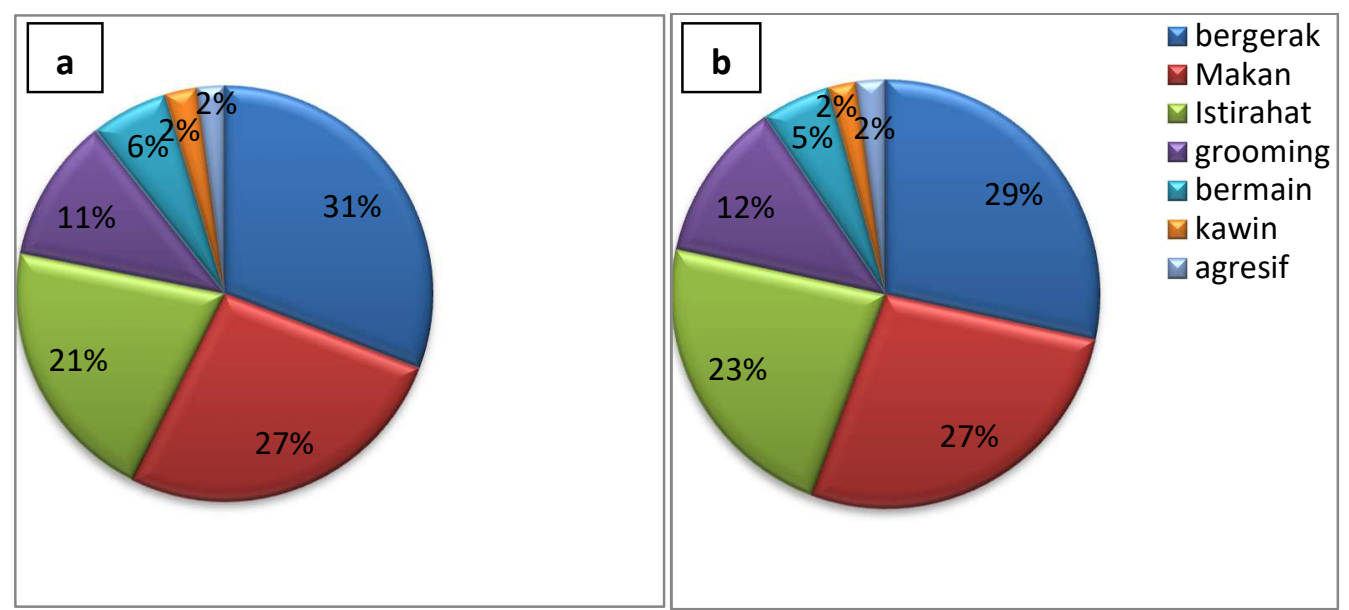

Gambar. 4 Perilaku kera ekor panjang jantan (a) dan betina (b) di Desa Pancasari.

\section{PEMBAHASAN}

Populasi kera ekor panjang (Macaca fascicularis) yang terdapat di Desa Pancasari adalah 252 ekor. Sebagian besar populasinya disusun oleh jantan dewasa, diikuti oleh betina dewasa,anakan dan yang paling sedikit adalah infan. Kera ekor panjang di pagi hari,lebih aktif bergerak untuk mencari makan di alam maupun di tempat pemberian pakan. Wahyu., dkk (2014) juga mendapatkan bahwa perilaku makan banyak dilakukan pada pagi hari.

Pada siang hari, kera lebih aktif bergerak untuk mencari makan dan juga disebabkan semakin banyaknya wisatawan yang berkunjung ke daerah tersebut dan memberi pakan pada kera. Putra (1996) dan Fuentes and Garmerl (2005) yang menyatakan bahwa kera banyak berkumpul di tempat yang dikunjungi oleh pengunjung.

Jenis-jenis makanan kera ekor panjang ( $M$ fascicularis) di Desa Pancasari antara lain pisang,jeruk, kacang dan dedaunan.Makanan yang banyak dimakan oleh kera ekor panjang adalah pisang (Musa sp.) diikuti jeruk, kacang dan dedaunan. Pisang merupakan makanan yang lebih banyak diberikan oleh pengelola dibandingkan dengan jeruk karena pisang memiliki harga yang lebih murah. Secara umum pisang disukai oleh kera ekor panjang karena memiliki kandungan nutrisi seperti karbohidrat, protein, vitamin, lemak dan air yang tinggi (Mudjajanto dan Kustiyah, 2012).

Jenis makanan berikutnya yang dipilih untuk dimakan oleh kera adalah kacang tanah (Arachis hypogea) dan dedaunan. Selain pisang dan jeruk, kacang juga disukai oleh kera ekor panjang yang ada di Desa Pancasari. Mudjajanto dan Kustiyah (2012) menyatakan bahwa kacang lebih diminati karena kandungan kalorinya lebih tinggi, namun ketersediannya dilapangan pada saat penelitian tidak sebanyak pisang

Perilaku kawin biasanya dilakukan pada waktu tertentu saja (Tarigan, 2009). Menurut Suprihandini (1993), perilaku kawin hanya dilakukan pada periode aktif dan terjadi pada waktu tertentu, dan biasanya perilaku kawin sering dilakukan pada saat pagi hari dan pada saat pemberian pakan oleh warga setempat. Hal ini sesuai dengan hasil penelitian Wahyu., dkk (2014) yaitu perilaku kera banyak dilakukan pada pagi hari.

Perilaku yang dilakukan oleh kera ekor panjang, jika dilihat dari waktu berperilakunya, sedikit bervariasi di pagi dan sore hari. Pagi hari, sebagian besar waktunya digunakan untuk bergerak, makan dan istirahat, dan sebagian lagi waktunya digunakan untuk grooming,bermain, kawin dan berperilaku agresif. Hal ini disebabkan kera ekor panjang lebih aktif bergerak pada 
pagi hari untuk mencari makananan, disamping aktivitas yang lain yang sering dilakukan. Perilaku agresif terjadi apabila ada kera lain mau menguasai atau mengambil makanan darikera ekor panjang jantan dewasa lainnya (Watiniasih, 2002). Sesuai dengan penelitian Saputra., (2013) yang menyatakan bahwa proporsi waktu yang digunakan oleh kera di pagi hari hampir sama dengan di sore hari.

Berdasarkan jenis kelamin, perilaku kera ekor panjang dewasa tidak banyak berbeda antara betina dan jantan. Waktu aktifnya banyak digunakan untuk makan dan bergerak, dan hanya sedikit waktunya digunakan untuk beristirahat, kawin dan agresif. Perilaku bergerak dan bermain biasanya banyak dilakukan oleh individu kera jantan dewasa, sementara untuk perilaku istirahat dan grooming biasanya lebih banyak dilakukan oleh individu kera betina dewasa.

Perilaku grooming biasanyta dilakukan oleh betina dewasa. Grooming adalah kegiatan mencari kutu yang biasanya dilakukan oleh kera ekor panjang. Grooming biasanya dilakukan dengan kedua tanganya (Kartikasari, 1986).

\section{SIMPULAN}

Jumlah populasi kera ekor panjang (Macaca fascicularis) di Desa Pancasari, Sukasada, Buleleng Baliadalah 252 ekor. Sebagian besar waktu aktifkera ini digunakan untuk bergerak, makan dan beristirahat dan sedikit di gunakan untuk grooming, bermain, kawin dan agresif.

\section{KEPUSTAKAAN}

Budayasih,N.L.1993. Studi Perbandingan Tingkah Laku Makan Monyet Berekor Panjang (Macaca fascicularis) di Taman Nasional Bali Barat dengan di Daerah Pulaki, Kabupaten Buleleng. Jurusan Biologi, (Skripsi). Fakultas Matematika dan Ilmu Pengetahuan Alam, Universitas Udayana, Bali.

Fooden, J. 2006. Comparative review of fascicularisgrooup species of macaques (primates: Macaca). Fieldiana: Zoology, n.s. 107:1-43.

Garmerl, M., A. Fuentes., G. Engel dan L. Jones-Engel. 2011. Future Directions for Research and Conservation. Of long-Tailed Macaque Populations. Di dalam: Gumert M, Fuentes A, Jones EL, Editor. Monkeys on the Edge: The ecology and Management of Long-tailed Macaque Populations and their Interface with Humans. Cambridge. UK: Cambridge University Press.

Kartikasari, S. N. 1986. Studi Populasi dan Perilaku Lutung (Presbytis cristata, Raffles) di Taman Nasional Baluran Jawa timur. (Skripsi) Jurusan Konservasi Sumberdaya Hutan. Fakultas Kehutanan IPB. Bogor.

Mudjajanto, E. S., dan L Kustiyah. 2012. Membuat Aneka Olahan. Available at: http://ridwanaz.com/resep/makanan/kandungan -gizi-buah-pisang/.

Putra, I. B. D. O. 1996. Tingkah Laku Makan Kera Ekor Panjang (Macaca fascicularis Raffles) Di
Hutan Wisata Alas Kedaton, Kecamatan Marga, Kabupaten Tabanan, Provinsi Bali. (Skripsi) Jurusan Biologi, Fakultas Matematika Dan Ilmu Pengetahuan Alam, Universitas Udayana, Bali.

Sajuthi, D. 1984. Satwa Primata Sebagai Hewan Laboratorium. Institut Pertanian Bogor. Bogor.

Saputra, K. G. W. 2013. Aktifitas Harian Dan Preferensi Makan Monyet Ekor Panjang (Macaca fascicularis) Di Taman Wisata Alam Sangeh, Kabupaten Badung, Bali. Jurusan Biologi, (Skripsi). Fakultas Matematika dan Ilmu Pengetahuan Alam, Universitas Udayana, Bali.

Supriatna, J.,E. H. dan Wahyono. 2000. Primata Indonesia. Panduan Lapangan. Yayasan Obor Indonesia. Jakarta.

Suprihandini, W. 1993. Studi Variasi Ritme Aktivitas Populasi Monyet Ekor Panjang (Macaca fascicularis Raffles 1821) Menurut Jenis Kelamin dan Kelas Kelompok Umur Di Pulau Tinjil Kabupaten Pandeglang Jawa Barat. (Skripsi) Fakultas Kehutanan, Institut Pertanian Bogor.Bogor.

Tarigan, B. 2009. Aktivitas Harian Monyet Ekor Panjang (Macaca fascicularis) di Kawasan Mandala Wisata Wenara Wana Padang tegal Ubud. (Skripsi) Fakultas Kedokteran Hewan Universitas Udayana. Bali.

Wahyu, Saputra. K. G., N. L. Watiniasih., dan I. K. Ginantra. 2014. Aktifitas Harian Kera Ekor Panjang (Macaca fascicularis) di Taman Wisata Alam Sangeh, Kabupaten Badung, Bali. Jurnal Biologi 18 (1):14-18.

Wahyu, Saputra. K. G., N. L. Watiniasih., dan I. K. Ginantra. 2014. Aktifitas Harian Kera Ekor Panjang (Macaca fascicularis) di Taman Wisata Alam Sangeh, Kabupaten Badung, Bali. Jurnal Biologi 18(1):14-18.

Watiniasih, N. L. 2002. Perilaku Monyet Ekor Panjang (Macaca fascicularis) di Wanara Wana Monkey Forest, Padang Tegal Ubud, Gianyar. Jurnal Biologi. 6 (2): 64-67. 